\title{
Effects of replacing grass silage with either maize or whole-crop wheat silages on the performance and meat quality of beef cattle offered two levels of concentrates
}

\author{
T. W. J. Keady ${ }^{1,2,3^{\dagger}}$, F. O. Lively ${ }^{1}$, D. J. Kilpatrick ${ }^{2,3}$ and B. W. Moss ${ }^{2,3}$ \\ ${ }^{1}$ Agricultural Research Institute of Northern Ireland, Hillsborough, Co. Down BT26 6DR, UK; ${ }^{2}$ Department of Agriculture and Rural Development for Northern \\ Ireland, Newforge Lane, Belfast BT9 5PX, UK; ${ }^{3}$ The Queen's University of Belfast, Newforge Lane, Belfast BT9 5PX, UK
}

(Received 16 May 2006; Accepted 25 December 2006)

\begin{abstract}
A randomised design involving 66 continental cross beef steers (initial live weight $523 \mathrm{~kg}$ ) was undertaken to evaluate the effects of the inclusion of maize or whole-crop wheat silages in grass silage-based diets on animal performance, carcass composition, and meat quality of beef cattle. Grass silage was offered either as the sole forage or in addition to either maize or whole-crop wheat silages at a ratio of 40:60, on a dry matter (DM) basis, alternative forage: grass silage. For the grass, maize, and wholecrop wheat silages, DM concentrations were 192, 276, and $319 \mathrm{~g} / \mathrm{kg}$, ammonia-nitrogen concentrations were 110, 90, and $150 \mathrm{~g} / \mathrm{kg}$ nitrogen, starch concentrations were not determined, 225, and $209 \mathrm{~g} / \mathrm{kg}$ DM and in vivo DM digestibilities were 0.69, 0.69 , and 0.58 ; respectively. The forages were offered ad libitum following mixing in a paddle type complete diet mixer wagon once per day, supplemented with either 3 or $5 \mathrm{~kg}$ concentrates per steer per day, in two equal feeds, for 92 days. For the grass, grass plus maize and grass plus whole-crop wheat silage-based diets food intakes were 8.38, 9.08, and 9.14 kg DM per day, estimated carcass gains were 514, 602, and 496 g/day and carcass weights were 326, 334, and $325 \mathrm{~kg}$; respectively. Altering the silage component of the diet did not influence carcass composition or meat eating quality. Increasing concentrate feed level tended $(\mathrm{P}=0.09)$ to increase estimated carcass fat concentration and increased sarcomere length $(\mathrm{P}<0.05)$, and lean $a^{*}(\mathrm{P}<0.01), b^{*}(\mathrm{P}<0.05)$, and chroma $(\mathrm{P}<0.01)$. There were no significant silage type by concentrate feed level interactions for food intake, steer performance, carcass characteristics or meat eating quality. It is concluded that replacing grass silage with maize silage increased carcass gain, and weight due to higher intakes, and improved utilisation of metabolisable energy. Whilst replacing grass silage with whole-crop wheat silage increased live-weight gain, the reduced dressing proportion resulted in no beneficial effect on carcass gain, probably due to increased food intakes of lower digestible forage increasing gut fill. Meat quality or carcass composition were not altered by the inclusion of maize or whole-crop silages in grass silage based diets.
\end{abstract}

Keywords: beef cattle, grass silage, maize silage, meat quality, whole-crop wheat silage

\section{Introduction}

Recent developments in plant breeding coupled with improvements in agronomic practices, particularly the development of the complete cover plastic mulch system have considerably increased the yield potential and feeding value of maize at more northern latitudes (Keady, 2005). Previous studies undertaken in Northern Ireland have shown that the yield potential of maize has increased from $4.1 \mathrm{t}$ dry matter (DM) per ha (McAllister, 1961) and $4.9 \mathrm{t}$ DM per ha (Bartholomew and Chestnutt, 1979) in the $1960 \mathrm{~s}$ and $1970 \mathrm{~s}$; respectively, to $12 \mathrm{t} \mathrm{DM}$ per ha in the

\footnotetext{
${ }^{\dagger}$ Current address: Teagasc, Livestock Production Centre, Athenry, Co. Galway, Ireland. E-mail: tim.keady@.teagasc.ie
}

late $1990 \mathrm{~s}$ (Easson, 2000) primarily due to improvements in plant breeding. The complete cover plastic mulch system, which involves total cover of the maize plants with unperforated plastic $6 \mu \mathrm{m}$ thick (the growing plant eventually forces through the degrading sheet), has considerably increased the yield potential of maize, as outlined by Keady (2003) the response to the complete cover plastic mulch system can be as high as $5 \mathrm{t}$ DM per ha depending on sowing date and variety sown.

Previous studies have shown that inclusion of maize silage in grass silage-based diets has had variable effects on animal performance. Incorporating maize silage into the diet has improved (Phipps et al., 1995; O'Kiely and Moloney, 2000; Keady et al., 2002b and 2003), had no effect 
(Hameleers, 1998) or reduced (O'Kiely and Moloney, 1995) animal performance. These different responses may have been due to variations in the feed value of both the grass and maize silages offered in these studies. More recently, Phipps et al. (2000) and Keady et al. (2002b) using dairy cows concluded that the optimum stage to harvest maize for improved animal performance was at approximately $300 \mathrm{~g} / \mathrm{kg}$.

Whole-crop wheat may be ensiled at DM concentrations ranging from 250 to $450 \mathrm{~g} / \mathrm{kg}$ if fermented, and 550 to $800 \mathrm{~g} / \mathrm{kg}$ if treated with urea or a urea-based additive to encourage an alkaline environment. Previous studies (Leaver and Hill, 1995; Phipps et al., 1995) have reported no difference in animal performance of dairy cows when either fermented or urea-treated whole-crop wheat silage were offered as a partial replacement for grass silage to lactating dairy cows.

Tenderness, colour and flavour are the major factors affecting meat quality (Buckley et al., 1995). Incorporating maize silage into grass silage based diets of beef cattle has altered (Hoving-Bolink et al., 1999) or had no effects (O'Sullivan et al., 2002) on meat quality. However there is a paucity of data on the effects of incorporating wholecrop wheat silages in grass silage based diets on subsequent meat quality of finishing beef cattle.

Grass silage is the basal forage offered to beef cattle in Ireland and the UK. Recent developments in plant breeding and agronomic practices in the production of alternative forages, coupled with their low costs of production (Keady, 2002a), has resulted in an increase in the production of maize and whole-crop wheat silages for feeding to beef cattle. There is a paucity of data where grass silage was replaced with either maize or whole-crop wheat silages in the same study on animal performance of, and subsequent meat quality from, finishing beef cattle. Therefore, the present study was undertaken to evaluate the effects of the inclusion of maize or whole-crop wheat silages in grass silage-based diets on animal performance, carcass composition, and meat quality of beef cattle.

\section{Material and methods}

\section{Forages}

Grass silage was harvested from the primary growth of predominantly perennial ryegrass swards between 27 and 29 May and ensiled following treatment with a bacterial inoculant (Ecosyl, Ecosyl Products Limited, Stokesley, North Yorkshire, England) at the rate of $3 \mathrm{l} / \mathrm{t}$ after a $3-\mathrm{h}$ wilting period. The herbage was mown using a mower fitted with a V-spoke grass conditioner and harvested using a self-propelled precision-chop forage harvester.

Whole-crop wheat was harvested at mealy stage (growth stage 11.2 on Feeke's scale (Large, 1954)) on 7 August from the winter variety Claire and ensiled treated with a bacterial inoculant (Wholecrop Gold, Biotal Ltd, Cardiff, Wales) at the rate of $4 \mathrm{l} / \mathrm{t}$.
Maize was harvested on 18 October from the variety Tassilo, which had been grown under the complete cover plastic mulch system, and ensiled treated with a bacterial inoculant and potassium sorbate additive (Ecocorn, Ecosyl Products Limited, Stokesley, North Yorkshire, England) applied at the rate of $2 \mathrm{l} / \mathrm{t}$.

The whole-crop wheat and maize silages were harvested direct cut using a self-propelled forage harvester (John Deere 6850, John Deere, Moline, Illinois, USA) fitted with a crimper header (Kemper model Champion 4500, Stadtlohn, Germany). The harvester was fitted with a corn cracker to crack the maize grains at the time of harvest. The forages were ensiled in trench silos. During filling, each silo was consolidated between loads by rolling with an industrial loader and for a further 60 min after filling was completed. Following consolidation two polythene sheets were used to seal each silo. The entire surface was then weighed down with a layer of tyres.

\section{Animals and management}

Grass silage was offered as the sole forage or in addition to either maize or whole-crop wheat silages at a ratio of 40:60 on a DM basis alternative forage: grass silage and supplemented with either 3 or $5 \mathrm{~kg}$ concentrates per steer per day. The six treatments were offered to 66 continental cross beef steers (mean age $=632$ days) with mean initial live weight of $523 \pm 37.2 \mathrm{~kg}$ in a randomised design experiment for 92 days. Eleven cattle were allocated to each of the six treatments at random balanced with respect to breed, live weight and conformation classification (European Carcass Classification Scheme (Kempster et al., 1982) undertaken on the live animals). For 2 months prior to the experiment the cattle received a medium feed value grass silage supplemented with $3 \mathrm{~kg}$ concentrate per day. The cattle were housed in slatted pens in two groups of four and one group of three per treatment.

The forages were mixed in a paddle type complete diet mixer wagon (Redrock, Armagh, Northern Ireland) for 5 min once daily and offered in sufficient quantities to allow a refusal of 50 to $100 \mathrm{~g} / \mathrm{kg}$ offered and were supplemented with either 3 or $5 \mathrm{~kg}$ concentrates per steer daily. The fresh weight of the forages to be placed in the mixer wagon, at a ratio of 40:60 on a DM basis alternative forage: grass silage was based on the daily DM concentrations of the silages offered the previous week. The blocks of silage were removed from the silos and transferred into the mixer wagon using a shear grab $(1.8 \mathrm{~m}$ cutting width). Concentrates were offered as a loose mix, unpelleted, in two meals daily, separate from the forages. The concentrates consisted of 500,120,200, 150, and $30 \mathrm{~g} / \mathrm{kg}$ barley, maize meal, sugar-beet pulp, soya bean, and molasses respectively. All cattle received $100 \mathrm{~g}$ of a beef mineral and vitamin mix per day (per kg: calcium $221 \mathrm{~g}$; phosphorus $40 \mathrm{~g}$; sodium $120 \mathrm{~g}$; magnesium $8 \mathrm{~g}$; cupric sulphate $1600 \mathrm{mg}$; sodium selenite $20 \mathrm{mg}$; retinol $120 \mathrm{mg}$; cholecalciferol $2 \mathrm{mg}$; alpha-tocopherol $1342 \mathrm{mg}$ ) with the concentrate feed offered in the afternoon. 
Measurements

Silage and concentrate intakes were recorded daily for the duration of the experiment. Silage DM intakes were calculated as described by Keady et al. (1994). Concentrates offered were sampled daily and bulked weekly for the determination of oven DM, crude protein (CP), ash, aciddetergent fibre (ADF), neutral-detergent fibre (NDF), gross energy (GE), and acid detergent insoluble nitrogen (ADIN).

Silages offered, and refusals, were sampled daily for determination of oven DM and dried samples of offered silage were bulked weekly for the determination of ADF, NDF, ADIN, and ash. Further composite sample of fresh offered silage was taken twice weekly and analysed for alcohols, GE, CP, ammonia nitrogen (N), acetate, propionate, butyrate, valerate, and lactate concentrations, buffering capacity, and $\mathrm{pH}$. A further composite sample of fresh silage was obtained once weekly and dried at $60^{\circ} \mathrm{C}$ for $48 \mathrm{~h}$ and analysed for water-soluble carbohydrate (WSC) concentration in grass silage and WSC and starch concentration in maize and whole-crop wheat silages.

Steers were weighed on two consecutive days at the beginning and end of the experiment and live-weight gain of each steer was calculated by difference using the mean of the two values. Seven steers per treatment consisting of one pen of four and one pen of three were slaughtered when the treatments had been imposed for 90 days and the remaining four were slaughtered after a further 6 days. The animals were stunned using a pneumatically operated captive bolt stunning system and bled immediately after stunning at an EU approved abbatoir which had routine veterinary inspection provided by the Department of Agriculture for Northern Ireland. Carcass weight was recorded for each steer at slaughter. Daily carcass gain was calculated for each steer, the initial carcass weight of each steer derived by using the relationship between live weight and carcass weight developed using similar steers (Keady and Kilpatrick, 2005). Carcass conformation and fat classification were determined by visual assessment according to the European Carcass Classification Scheme as described by Kempster et al. (1982). The weights of kidney, cod and channel fat were recorded for every animal during the dressing procedure. All carcasses were changed from achilles suspension at 45 min post mortem to suspension from the aitch bone (tenderstretch) and chilled under standard commercial conditions. The carcasses were placed in a chill subjected to an air temperature of $10^{\circ} \mathrm{C}$ for $10 \mathrm{~h}$ after which the air temperature was reduced to $1^{\circ} \mathrm{C}$ for 24 hours. Subsequently the carcasses were stored at 2 to $4^{\circ} \mathrm{C}$. At $48 \mathrm{~h}$ post mortem the carcass was quartered between the 10th and 11th ribs and the depth of subcutaneous fat was measured $(\mathrm{mm})$ at points $0.25,0.50$, and 0.75 over the $\mathrm{m}$. longissimus dorsi (LD). Marbling of the LD was assessed using the eight-point scale of the United States Department of Agriculture photographic standards (Agricultural Research Council, 1965). The area of the LD muscle at the tenth rib on each side of the carcass was determined from a photograph using a PC image programme
(Foster Findlay Assosiates Ltd, Newcastle Technopole, Kings Manor, Newcastle upon Tyne, England). Sampling for sarcomere length determination was as described by Koolmees et al. (1986). Prepared samples were measured by laser diffraction (Cross et al., 1981).

The sample joint (termed fore-rib in the UK, 6/7 rib to $10 / 11 \mathrm{rib}$ ) was removed from the left forequarter of each carcass. A cut was made between the 6 th and 7 th ribs from the backbone to a point not more than $5 \mathrm{~cm}$ from the lateral tip of the LD. The joint was removed from the flank portion by making a cut perpendicular to the ribs $5 \mathrm{~cm}$ from the lateral tip of the LD. At 7 days post mortem the LD was removed from the fore-rib joint for meat quality assessment. The fore-rib joint was retained for dissection into lean, fat and bone as described by Cuthbertson et al. (1972). The composition of the carcass of each individual animal was estimated from the composition of its fore-rib joint using the equations given by Steen and Robson (1995) for animals that were considered to be of predominantly Charolais breeding, and using the small adjustments to the first-term constants in these equations for the Simmental cross animals as given by Steen and Kilpatrick (2000) and for Limousin and Blonde d'Aquitaine crosses as given by Steen and Kilpatrick (1995). The quantity of lean previously removed for analysis was added back prior to calculation.

A $3 \mathrm{~cm}$ steak of LD was removed at the 11 th rib with the freshly cut side facing upwards and left to bloom for $1 \mathrm{~h}$ prior to measuring lean and fat colour at 7 days post mortem by reflectance spectra $(380$ to $800 \mathrm{~nm})$ at $1 \mathrm{~nm}$ intervals using the Monolight Spectrophotometer, Model 6800 Controller fitted with a $0 / 45^{\circ}$ Reflectance head (Monolight Instruments Ltd, Weybridge, England). The colour space values, $L^{*}$ (lightness), $a^{*}$ (redness), and b* yellowness, were calculated according to CIE (Commission Internationale de l'Eclairage) specifications using the software supplied by Monolight Instruments (UK) Ltd.

A $1 \mathrm{~g}$ sample of LD muscle was taken from the freshly cut surface and homogenised in $10 \mathrm{ml}$ of distilled water and the $\mathrm{pH}$ of the homogenate measured using a Sentron $\mathrm{pH}$ meter, 7 days post mortem.

Cooking loss and shear force were assessed at 7 days post mortem on a 35 to $40 \mathrm{~mm}$ thick slice of the LD cut transverse to the muscle fibre direction from the posterior end of the fore-rib. Steak slices $35 \mathrm{~mm}$ thick were weighed and placed in a polythene bag and cooked by placing in a water bath at $75^{\circ} \mathrm{C}$ for $50 \mathrm{~min}$, after this time the mean internal temperature was $71^{\circ} \mathrm{C}$ (range 70 to $72^{\circ} \mathrm{C}$ ). Subsequently the slices were cooled in an ice water bath for $1 \mathrm{~h}$ with subsequent storage in a cold room at $4^{\circ} \mathrm{C}$, such that the core temperature at shearing was 4 to $5^{\circ} \mathrm{C}$. Excess liquid was removed by gently patting the slices with absorbent paper toweling, and the slices then re-weighed to calculate cooking losses. Ten cores $12.7 \mathrm{~mm}$ diameter were drilled from each slice paralled to the muscle fibre direction and sheared transversely on a Warner Bratzler shear blade fitted to a Model 6021 Instron Universal Testing Instrument (Instron, High Wycombe, Buckinghamshire, England). 
Twelve additional steers (two per treatment) of similar live weight to the experimental steers that had been given the diets for 20 days, were used to determine the total tract digestibilities and $\mathrm{N}$ retention for the total diets. Procedures for the determination of digestibilities were as described by Steen (1984). The metabolisable energy (ME) concentrations of the diets were calculated as described by Keady et al. (1994). In addition, apparent digestibilities of the forages offered at maintenance were determined using four castrate male sheep (Texel $\times$ Greyface, 1.5 years) per silage. The silage for the apparent digestibility study using sheep was removed, as described by Keady et al. (1998).

Corrected silage DM was determined as described by Porter and Murray (2001). Chemical composition of silage, concentrates, urine and faeces were determined as described by Keady et al. (1998 and 1999).

\section{Statistical analysis}

Animal performance and carcass data were analysed as randomised designs using a factorial model to test for the main effects of silage type and concentrate feed level plus their interactions. For the analysis of variance of liveweight gain, carcass gain, carcass data, meat quality assessments, carcass composition, and diet digestibilities, each steer was treated as an individual, while for food intake the mean values obtained for each group of three or four steers were used. Animal performance data were adjusted by covariance analysis using initial live weight as a covariate and food intakes were adjusted using the 7 day pre-experimental intake and initial live weight as covariates. Silage and total ration digestibilities were analysed as randomised design experiments. When significant
$(P<0.05)$ main effects were found, differences between the individual factor levels were tested using Students $t$ test.

\section{Results}

Chemical composition of the silages and concentrates The chemical composition of the silages and concentrates offered in the present study are presented in Table 1. The silages were well preserved as indicated by their $\mathrm{pH}$ and concentrations of ammonia $\mathrm{N}$ and butyrate. The DM concentration of the grass silage was low, being $192 \mathrm{~g} / \mathrm{kg}$ while for the maize and whole-crop wheat silages the DM concentrations were 276 and $319 \mathrm{~g} / \mathrm{kg}$; respectively. The maize and whole-crop wheat silages had starch concentrations of 225 and $209 \mathrm{~g} / \mathrm{kg}$, respectively.

Silage digestibilities determined through sheep at maintenance level are presented in Table 2 . Relative to the grass silage, maize silage had lower $(P<0.001)$ ADF and NDF digestibilities but similar DM digestibility and digestible organic matter in the DM (DOMD). Relative to the grass and maize silages, the whole-crop wheat had significantly lower $(P<0.001)$ DM, ADF and NDF digestibilities and DOMD.

\section{Steer performance}

The effects of silage type and concentrate feed level on food and energy intakes are presented in Table 3. There were no silage type by concentrate feed level interactions for food or energy intakes. Inclusion of either maize or whole-crop wheat silage in the diet increased forage DM $(P<0.01)$, total DM, $(P<0.01)$ and GE $(P<0.05)$

Table 1 Chemical composition of the silages and concentrates as fed

\begin{tabular}{|c|c|c|c|c|}
\hline & \multicolumn{3}{|c|}{ Silage } & \multirow[b]{2}{*}{ Concentrates } \\
\hline & Grass & Maize & Whole crop wheat & \\
\hline Dry matter (g/kg) & 192 & 276 & 319 & 834 \\
\hline $\mathrm{pH}$ & 4.23 & 4.11 & 4.25 & - \\
\hline \multicolumn{5}{|l|}{ Composition of DM $(\mathrm{g} / \mathrm{kg})$} \\
\hline Crude protein & 116 & 80 & 98 & 171 \\
\hline Ammonia N (g/kg N) & 110 & 90 & 150 & - \\
\hline Ethanol & 21.1 & 13.2 & 5.9 & - \\
\hline Propanol & 21.1 & 13.3 & 6.5 & - \\
\hline Acetate & 64 & 48 & 41 & - \\
\hline Propionate & 3.0 & 1.2 & 8.0 & - \\
\hline Butyrate & 1.0 & 0.2 & 2.4 & - \\
\hline Valerate & 0.1 & 0.2 & 0.4 & - \\
\hline Lactate & 30.6 & 14.1 & 16.2 & - \\
\hline Acid detergent fibre & 376 & 279 & 314 & 88 \\
\hline Acid detergent insoluble nitrogen & 1.89 & 0.99 & 1.37 & 1.36 \\
\hline Neutral detergent fibre & 604 & 539 & 536 & 212 \\
\hline Water soluble carbohydrate & 5.0 & 4.4 & 4.8 & - \\
\hline Ash & 77.5 & 37.1 & 47.1 & 47.6 \\
\hline Starch & - & 225 & 209 & - \\
\hline Gross energy (MJ/kg DM) & 19.26 & 19.22 & 18.58 & 18.18 \\
\hline
\end{tabular}


Table 2 Silage digestibilities determined through sheep at maintenance level

\begin{tabular}{|c|c|c|c|c|c|}
\hline & \multicolumn{3}{|c|}{ Silage } & \multirow[b]{2}{*}{ s.e. } & \multirow[b]{2}{*}{$\mathrm{Sig}^{\dagger}$} \\
\hline & Grass & Maize & Whole crop wheat & & \\
\hline \multicolumn{6}{|l|}{ Digestibility coefficient } \\
\hline Dry matter & $0.692^{\mathrm{b}}$ & $0.686^{\mathrm{b}}$ & $0.580^{\mathrm{a}}$ & 0.0064 & *** \\
\hline $\mathrm{DOMD}^{\ddagger}(\mathrm{g} / \mathrm{kg} \mathrm{DM})$ & $662^{\mathrm{b}}$ & $675^{\mathrm{b}}$ & $566^{\mathrm{a}}$ & 5.74 & $* * *$ \\
\hline Acid detergent fibre & $0.762^{c}$ & $0.582^{b}$ & $0.427^{a}$ & 0.0101 & *** \\
\hline Neutral detergent fibre & $0.717^{c}$ & $0.569^{b}$ & $0.398^{\mathrm{a}}$ & 0.0101 & *** \\
\hline
\end{tabular}

${ }^{\dagger}$ Means within a row having a different superscript differ, $(P<0.05)$.

NS $P>0.05 ;{ }^{*} P<0.05 ;{ }^{* *} P<0.01 ;{ }^{* *} P<0.001$.

${ }^{\ddagger}$ Digestible organic matter in the DM.

intakes. Maize silage inclusion increased digestible energy (DE) intake $(P<0.05)$ and tended $(P=0.08)$ to increase ME intake.

Increasing concentrate feed level significantly decreased $(P<0.001)$ forage DM and increased total DM $(P<0.001)$, DE $(P<0.001)$, ME $(P<0.001)$ and $\mathrm{GE}$ $(P<0.01)$ intakes.

The effects of silage type and concentrate feed level on steer performance and carcass assessments are presented in Table 4. Relative to grass silage only, inclusion of maize silage in the diet increased $(P<0.05)$ final live weight, live-weight gain, carcass weight, and estimated carcass gain. Whole-crop wheat silage inclusion increased $(P<0.05)$ final live weight and live-weight gain and decreased $(P<0.05)$ dressing proportion relative to grass silage. Inclusion of either maize or whole-crop wheat silages did not alter $(P>0.05)$ carcass conformation or fat classification, mean fat depth over LD, marbling score, area of LD muscle at 10th rib, kidney, channel and cod fat, the lean, fat and bone contents of the fore-rib joint or estimated lean, fat or bone contents. Increasing concentrate feed level tended to increase live-weight gain $(P=0.07)$, marbling score $(P=0.06)$ and the weight of kidney, channel and cod fat $(P=0.06)$. Concentrate feed level did not alter $(P>0.05)$ final live weight, carcass weight, dressing proportion, estimated carcass gain, carcass conformation or fat classification, mean fat depth over, or area of the LD muscle, the lean and bone contents of the fore-rib joint, or estimated lean and bone content of the carcass. Increasing concentrate feed level tended $(P=0.09)$ to increase the fat content of the fore-rib and estimated fat content of the carcass. There were no silage type by concentrate feed level interactions for steer performance or carcass assessments.

The effect of silage type and concentrate feed level on fat and lean colour and meat quality is presented in Table 5. Increasing concentrate feed level increased $a^{*}$ $(P<0.01), b^{*}(P<0.05)$, and chroma $(P<0.01)$ for lean colour and sarcomere length $(P<0.05)$. Otherwise silage type or concentrate feed level did not alter fat or lean colour, $\mathrm{pH}$, cooking loss or Warner Bratzler shear force. There were no silage type by concentrate feed level interactions for fat and lean colour or meat quality.

The effects of silage type and concentrate feed level on total diet digestibilities and $\mathrm{N}$ retention are presented in Table 6. Inclusion of maize silage in the diet decreased $(P<0.05)$ ADF and NDF digestibilities and increased $(P<0.05) \mathrm{N}$ retention compared with grass silage-based diets. Maize silage inclusion in the diet did not alter $(P>0.05) \mathrm{DM}$, organic matter $(\mathrm{OM})$, or energy digestibilities,

Table 3 Effects of silage type and concentrate feed level on dry matter and energy intakes

\begin{tabular}{|c|c|c|c|c|c|c|c|c|c|c|}
\hline & \multicolumn{3}{|c|}{ Silage (S) } & \multirow[b]{2}{*}{ s.e. } & \multicolumn{2}{|c|}{$\begin{array}{l}\text { Concentrate } \\
\text { (kg/day) (C) }\end{array}$} & \multirow[b]{2}{*}{ s.e. } & \multicolumn{3}{|c|}{ Significance $^{\dagger}$} \\
\hline & Grass & $\begin{array}{c}\text { Grass } \\
\text { plus maize }\end{array}$ & $\begin{array}{c}\text { Grass } \\
\text { plus whole crop wheat }\end{array}$ & & 3 & 5 & & $S$ & C & $\mathrm{S} \times \mathrm{C}$ \\
\hline $\begin{array}{l}\text { Forage } \\
\text { intake (kg DM/day) }\end{array}$ & $5.05^{\mathrm{a}}$ & $5.75^{\mathrm{b}}$ & $5.80^{b}$ & 0.153 & $5.96^{\mathrm{b}}$ & $5.10^{\mathrm{a}}$ & 0.128 & ** & $* * *$ & NS \\
\hline $\begin{array}{l}\text { Total food } \\
\text { intake (kg DM/day) }\end{array}$ & $8.38^{\mathrm{a}}$ & $9.08^{b}$ & $9.14^{b}$ & 0.153 & $8.46^{\mathrm{a}}$ & $9.23^{b}$ & 0.128 & ** & $* * *$ & NS \\
\hline $\begin{array}{l}\text { Gross energy } \\
\text { intake (MJ/day) }\end{array}$ & $158^{\mathrm{a}}$ & $172^{b}$ & $171^{b}$ & 2.9 & $160^{\mathrm{a}}$ & $174^{b}$ & 2.5 & * & ** & NS \\
\hline $\begin{array}{l}\text { Digestible energy } \\
\text { intake (MJ/day) }\end{array}$ & $121^{\mathrm{a}}$ & $130^{b}$ & $127^{\mathrm{ab}}$ & 2.2 & $120^{\mathrm{a}}$ & $132^{b}$ & 1.9 & * & $* * *$ & NS \\
\hline $\begin{array}{l}\text { Metabolisable energy } \\
\text { intake (MJ/day) }\end{array}$ & 104 & 111 & 108 & 1.9 & $102^{\mathrm{a}}$ & $113^{b}$ & 1.6 & $P=0.08$ & $* * *$ & NS \\
\hline
\end{tabular}

${ }^{\dagger}$ Means within a row for silage type of concentrate feed level having a different superscript differ, $(P<0.05)$.

NS $P>0.05 ;{ }^{*} P<0.05 ;{ }^{* *} P<0.01 ;{ }^{* *} P<0.001$. 
Keady, Lively, Kilpatrick and Moss

Table 4 Effects of silage type and concentrate feed level on animal performance and carcass assessments

\begin{tabular}{|c|c|c|c|c|c|c|c|c|c|}
\hline & \multicolumn{3}{|c|}{ Silage $(S)$} & \multirow[b]{2}{*}{ s.e. } & \multicolumn{2}{|c|}{$\begin{array}{l}\text { Concentrate } \\
\text { (kg/day) (C) }\end{array}$} & \multirow[b]{2}{*}{ s.e. } & \multicolumn{2}{|c|}{ Significance $^{\dagger}$} \\
\hline & Grass & Grass plus maize & Grass plus whole crop wheat & & 3 & 5 & & $S$ & C \\
\hline Final live weight (kg) & $601^{\mathrm{a}}$ & $621^{b}$ & $614^{b}$ & 4.3 & 608 & 616 & 3.5 & * & NS \\
\hline Live-weight gain (kg/day) & $0.86^{\mathrm{a}}$ & $1.07^{b}$ & $1.01^{\mathrm{b}}$ & 0.042 & 0.93 & 1.03 & 0.034 & * & $P=0.07$ \\
\hline Carcass weight $(\mathrm{kg})$ & $326^{a}$ & $334^{\mathrm{b}}$ & $325^{\mathrm{a}}$ & 3.0 & 326 & 331 & 2.4 & * & NS \\
\hline $\begin{array}{l}\text { Dressing proportion } \\
\text { ( } \mathrm{g} \text { carcass per } \mathrm{kg} \text { live weight) }\end{array}$ & $543^{b}$ & $539^{b}$ & $528^{\mathrm{a}}$ & 3.5 & 537 & 537 & 2.8 & * & NS \\
\hline Estimated carcass gain (g/day) & $514^{\mathrm{a}}$ & $602^{\mathrm{b}}$ & $496^{\mathrm{a}}$ & 31.4 & 515 & 560 & 25.6 & * & NS \\
\hline Carcass conformation ${ }^{\ddagger}$ & 2.75 & 2.82 & 2.77 & 0.072 & 2.79 & 2.77 & 0.059 & NS & NS \\
\hline Carcass fat classification $^{5}$ & 3.25 & 3.77 & 3.52 & 0.161 & 3.35 & 3.68 & 0.132 & NS & NS \\
\hline $\begin{array}{l}\text { Mean fat depth over longissimus } \\
\text { dorsi muscle (mm) }\end{array}$ & 4.63 & 5.49 & 5.83 & 0.395 & 4.98 & 5.66 & 0.323 & NS & NS \\
\hline Marbling score" & 2.23 & 2.45 & 2.41 & 0.145 & 2.18 & 2.54 & 0.118 & NS & 0.06 \\
\hline $\begin{array}{l}\text { Area of longissimus dorsi muscle } \\
\text { at } 10^{\text {th }} \mathrm{rib}\left(\mathrm{cm}^{2}\right)\end{array}$ & 69.8 & 69.3 & 67.8 & 1.80 & 68.8 & 69.1 & 1.47 & NS & NS \\
\hline $\begin{array}{l}\text { Kidney, channel and } \\
\text { cod fat }(\mathrm{kg})\end{array}$ & 14.8 & 17.0 & 15.7 & 0.74 & 15.0 & 16.7 & 0.60 & NS & 0.06 \\
\hline \multicolumn{10}{|l|}{$\begin{array}{l}\text { Composition of fore-rib } \\
\text { joint }(\mathrm{g} / \mathrm{kg})\end{array}$} \\
\hline lean concentration & 592 & 591 & 582 & 8.0 & 596 & 580 & 6.5 & NS & NS \\
\hline fat concentration & 209 & 214 & 212 & 9.9 & 201 & 222 & 8.1 & NS & $P=0.09$ \\
\hline bone concentration & 191 & 188 & 200 & 4.4 & 195 & 191 & 3.6 & NS & NS \\
\hline \multicolumn{10}{|l|}{$\begin{array}{l}\text { Estimated carcass } \\
\text { composition (g/kg) }\end{array}$} \\
\hline lean concentration & 651 & 650 & 645 & 4.8 & 654 & 644 & 3.9 & NS & NS \\
\hline fat concentration & 158 & 161 & 159 & 6.1 & 153 & 166 & 5.0 & NS & $P=0.09$ \\
\hline bone concentration & 183 & 182 & 186 & 1.7 & 184 & 183 & 1.4 & NS & NS \\
\hline
\end{tabular}

${ }^{\dagger}$ Means within a row having a different superscript differ, $(P<0.05)$.

‡EUROP scale: 5 (best), 4, 3, 2, 1 (worst); respectively.

${ }^{\S}$ Five-point scale: $1=$ leanest, $5=$ fattest.

" Eight-point scale: $1=$ leanest, $8=$ fattest.

NS $P>0.05 ;{ }^{*} P<0.05 ;{ }^{*} P<0.01 ;{ }^{* *} P<0.001$.

There were no significant silage type by concentrate interactions.

DOMD or ME concentration of the total diet. Relative to grass silage, inclusion of whole-crop wheat silage decreased DM $(P<0.05)$, OM $(P<0.05)$, ADF $(P<0.001)$, NDF $(P<0.001)$, and energy $(P<0.05)$ digestibilities, DOMD $(P<0.05)$ and ME concentration $(P<0.05)$ and increased $\mathrm{N}$ retention $(P<0.05)$ and starch digestibility $(P<0.05)$ of total diet. Relative to the inclusion of maize silage, inclusion of whole-crop wheat silage decreased $(P<0.05) \mathrm{DM}, \mathrm{OM}$, $A D F, N D F$, and energy digestibilities of the total diet. Increasing concentrate feed level increased OM $(P<0.05)$ digestibility and DOMD $(P<0.01)$ and did not alter $(P>0.05)$ DM, ADF, NDF, energy, $N$ or starch digestibilities, ME concentrations or $\mathrm{N}$ retention. There were no silage type by concentrate feed level interactions $(P>0.05)$ on diet digestibilities, ME concentration, or $\mathrm{N}$ retention of the total diets.

\section{Discussion}

While the main aim of the present study was to establish the effects of replacing grass silage with alternative forages on feed intake and animal performance of beef cattle, the study also provided the opportunity to compare maize and whole-crop wheat. Furthermore, potential interactions between forage type and concentrate feed level were also studied. The concentrate was formulated so that the diet with the lowest CP concentration would have sufficient protein to meet animal requirements. Inadequate intakes of protein have been found to have detrimental effects on live-weight gain and carcass composition of beef cattle (Lindsay and Davies, 1981).

The grass silage used in the present study was representative of the average silage produced in Ireland. Keady (2000) quoted mean pH and concentrations of DM, CP, ammonia $\mathrm{N}$ and DM digestibility of grass silage analysed by the Hillsborough Feeding Information System of 4.1, $230 \mathrm{~g} / \mathrm{kg}$ fresh, $127 \mathrm{~g} / \mathrm{kg} \mathrm{DM}, 120 \mathrm{~g} / \mathrm{kg} \mathrm{DM}$, and $700 \mathrm{~g} / \mathrm{kg}$ DM; respectively. The maize silage offered in the present study had a DM concentration of $276 \mathrm{~g} / \mathrm{kg}$ fresh which was near the optimum stage of maturity at harvest. Phipps et al. (2000) and Keady et al. (2002b) using dairy cows previously concluded that the optimum stage of maturity to harvest maize for ensiling to maximise animal performance was approximately $300 \mathrm{~g} / \mathrm{kg}$ fresh. The fermented wholecrop wheat silage offered in the present study had a DM 
Silage type and performance and meat quality in beef cattle

Table 5 Effects of silage type and concentrate feed level on fat and lean colour and meat quality

\begin{tabular}{|c|c|c|c|c|c|c|c|c|c|}
\hline & \multicolumn{3}{|c|}{ Silage (S) } & \multirow[b]{2}{*}{ s.e. } & \multicolumn{2}{|c|}{$\begin{array}{l}\text { Concentrate } \\
\text { (kg/day) (C) }\end{array}$} & \multirow[b]{2}{*}{ s.e. } & \multicolumn{2}{|c|}{$\begin{array}{l}\text { Signifi- } \\
\text { cance }^{+}\end{array}$} \\
\hline & Grass & $\begin{array}{l}\text { Grass plus } \\
\text { maize }\end{array}$ & $\begin{array}{c}\text { Grass plus } \\
\text { whole-crop wheat }\end{array}$ & & 3 & 5 & & $S$ & $C$ \\
\hline \multicolumn{10}{|l|}{ Fat colour } \\
\hline$L^{*}$ & 71.4 & 71.9 & 72.6 & 2.07 & 73.9 & 70.0 & 1.69 & NS & NS \\
\hline$a^{*}$ & 5.7 & 7.1 & 5.5 & 1.01 & 5.7 & 6.5 & 0.83 & NS & NS \\
\hline$b^{*}$ & 16.6 & 17.9 & 17.9 & 0.89 & 17.3 & 17.6 & 0.72 & NS & NS \\
\hline Chroma & 17.9 & 19.5 & 18.8 & 1.11 & 18.5 & 18.9 & 0.90 & NS & NS \\
\hline Hue & 71.7 & 69.6 & 73.7 & 2.47 & 73.0 & 70.4 & 2.01 & NS & NS \\
\hline \multicolumn{10}{|l|}{ Lean colour } \\
\hline$L^{*}$ & 42.2 & 40.7 & 41.4 & 0.87 & 41.0 & 41.9 & 0.71 & NS & NS \\
\hline$a^{*}$ & 20.7 & 21.4 & 20.9 & 0.51 & $20.0^{a}$ & $22.0^{\mathrm{b}}$ & 0.42 & NS & ** \\
\hline$b^{*}$ & 15.9 & 16.2 & 15.9 & 0.37 & $15.4^{a}$ & $16.6^{\mathrm{b}}$ & 0.31 & NS & * \\
\hline Chroma & 26.1 & 26.8 & 26.3 & 0.59 & $25.2^{\mathrm{a}}$ & $27.6^{\mathrm{b}}$ & 0.48 & NS & ** \\
\hline Hue & 37.6 & 37.2 & 37.4 & 0.52 & 37.6 & 37.2 & 0.43 & NS & NS \\
\hline $\mathrm{pH}$ & 5.57 & 5.56 & 5.55 & 0.011 & 5.56 & 5.56 & 0.009 & NS & NS \\
\hline Sarcomere length $(\mu \mathrm{m})$ & 2.28 & 2.29 & 2.34 & 0.055 & $2.23^{\mathrm{a}}$ & $2.38^{\mathrm{b}}$ & 0.050 & NS & * \\
\hline Cooking loss (\%) & 26.2 & 26.5 & 26.1 & 0.97 & 26.1 & 26.4 & 0.79 & NS & NS \\
\hline Warner Bratzler shear force $(\mathrm{kg})$ & 2.64 & 2.75 & 2.65 & 0.23 & 2.73 & 2.63 & 0.187 & NS & NS \\
\hline
\end{tabular}

${ }^{t a, b}$ Means within a row having a different superscript differ significantly $(P<0.05)$.

NS $P>0.05 ;{ }^{*} P<0.05 ;{ }^{* *} P<0.01 ;{ }^{* * *} P<0.001$.

There were no significant silage type by concentrate interactions.

concentration of $310 \mathrm{~g} / \mathrm{kg}$, and Sinclair et al. (2003) have shown that ensiling whole-crop wheat at DM concentrations between 300 and $370 \mathrm{~g} / \mathrm{kg}$ did not affect animal performance of dairy cows.

Due to the absence of forage by concentrate feed level interactions only the main treatment effects are discussed.

\section{Feed intake}

In the present study alternative forages accounted for proportionately 0.40 and 0.25 of forage and total DM intakes respectively. Previous studies have reported increased food intake due to the inclusion of maize silage in the diet of beef cattle (Browne et al., 1999; O'Kiely and Moloney, 1995 and 2000) and dairy cows (Phipps et al., 2000; Keady et al., 2002b and 2003). However, Keady et al. (2002b and 2003) concluded that the factor which had the greatest effect on the response to the inclusion of maize silage in grass silage-based diets offered to dairy cows was grass silage quality. For example, Keady et al. (2002b) replaced 0.40 of low (ME $9.8 \mathrm{MJ} / \mathrm{kg} \mathrm{DM}$ ) and high (ME $11.8 \mathrm{MJ} / \mathrm{kg}$ DM) feed value grass silages with a range of maize silages differing in maturity at harvest and concluded that varying

Table 6 Effects of silage type and concentrate feed level on total diet digestibilities and nitrogen retention

\begin{tabular}{|c|c|c|c|c|c|c|c|c|c|}
\hline & \multicolumn{3}{|c|}{ Silage (S) } & \multirow[b]{2}{*}{ s.e. } & \multicolumn{2}{|c|}{$\begin{array}{l}\text { Concentrate } \\
\text { (kg/day) (C) }\end{array}$} & \multirow[b]{2}{*}{ s.e. } & \multicolumn{2}{|c|}{$\begin{array}{l}\text { Signifi- } \\
\text { cance }^{+}\end{array}$} \\
\hline & Grass & $\begin{array}{l}\text { Grass plus } \\
\text { maize }\end{array}$ & $\begin{array}{c}\text { Grass plus } \\
\text { whole crop wheat }\end{array}$ & & 3 & 5 & & $S$ & C \\
\hline \multicolumn{10}{|l|}{ Digestibility coefficient } \\
\hline Dry matter & $0.765^{\mathrm{b}}$ & $0.760^{\mathrm{b}}$ & $0.743^{\mathrm{a}}$ & 0.0048 & 0.750 & 0.763 & 0.0039 & * & NS \\
\hline Organic matter & $0.782^{b}$ & $0.770^{b}$ & $0.753^{a}$ & 0.0048 & $0.761^{a}$ & $0.776^{\mathrm{b}}$ & 0.0039 & * & * \\
\hline DOMD (g/kg DM) & $689^{b}$ & $684^{\mathrm{ab}}$ & $667^{a}$ & 4.5 & $668^{a}$ & $692^{\mathrm{b}}$ & 3.7 & * & ** \\
\hline Acid detergent fibre & $0.747^{c}$ & $0.709^{b}$ & $0.670^{a}$ & 0.0075 & 0.716 & 0.701 & 0.006 & $* * *$ & NS \\
\hline Neutral detergent fibre & $0.728^{\mathrm{C}}$ & $0.684^{b}$ & $0.658^{\mathrm{a}}$ & 0.0087 & 0.700 & 0.680 & 0.0071 & $* *$ & NS \\
\hline Energy & $0.768^{b}$ & $0.760^{b}$ & $0.743^{\mathrm{a}}$ & 0.0052 & 0.752 & 0.762 & 0.0042 & * & NS \\
\hline Nitrogen & 0.689 & 0.699 & 0.716 & 0.0129 & 0.698 & 0.705 & 0.0105 & NS & NS \\
\hline Starch & $0.974^{\mathrm{a}}$ & $0.981^{\mathrm{ab}}$ & $0.986^{\mathrm{b}}$ & 0.0024 & 0.982 & 0.979 & 0.0020 & * & NS \\
\hline ME (MJ/kg DM) & $12.41^{\mathrm{b}}$ & $12.22^{\mathrm{ab}}$ & $11.80^{\mathrm{a}}$ & 0.131 & 12.08 & 12.20 & 0.107 & * & NS \\
\hline Nitrogen retention (g/day) & $17.8^{\mathrm{a}}$ & $25.6^{\mathrm{b}}$ & $28.0^{b}$ & 1.84 & 23.9 & 23.7 & 1.50 & * & NS \\
\hline
\end{tabular}

${ }^{\dagger}$ Means within a row having a different superscript differ, $(P<0.05)$.

NS $P>0.05 ;{ }^{*} P<0.05 ;{ }^{* *} P<0.01 ;{ }^{* *} P<0.001$.

There were no significant silage type by concentrate interactions. 
DM of maize silage from 201 to $384 \mathrm{~g} / \mathrm{kg}$ fresh had no effect on total DM intake. However for the low and high feed value grass silage-based diets, replacement of 0.40 of the grass silage with maize resulted in total DM intakes of 1.15 and 0.99 relative to the grass silage- based diet. Similarly, Keady et al. (2003) observed that for low (ME 10.2 $\mathrm{MJ} / \mathrm{kg} \mathrm{DM}$ ), medium (ME 11.0 MJ/kg DM), and high (ME $12.0 \mathrm{MJ} / \mathrm{kg} \mathrm{DM}$ ) feed value grass silages, replacement with 0.4 of the grass silage component of the diet with maize resulted in total DM intake by dairy cows of 1.12, 1.09, and 0.99; respectively relative to grass silage-based diets. The increased food intake due to the inclusion of maize silage in the present study is similar to the mean response reported by Keady et al. (2002b and 2003).

Steen et al. (1998) concluded that the main factors affecting grass silage intake were forage digestibility, rumen degradability, and the concentrations of $\mathrm{N}$ and fibre fractions. The increased intake characteristics of maize silage are not fully explained by the findings of Steen et al. (1998). Steen et al. (1998) and Keady et al. (2004) developed models to predict food intake of grass silage and mixed forage-based diets by beef and dairy cattle; respectively. The models of Steen et al. (1998) and Keady et al. (2004) predicted an increase in feed intake of 0.524 and $0.65 \mathrm{~kg} \mathrm{DM}$ per head per day, or 0.07 and 0.06 in forage intake; respectively due to the inclusion of maize silage. The use of these prediction models to predict intake of mixed forage-based diets illustrated that the higher intake characteristics of maize silage can be attributed to a combination of DM, fermentation and digestibility characteristics, and lower concentrations of NDF and ADF.

Previous authors have reported that the inclusion of whole-crop wheat silage in grass silage-based diets has increased forage intake of beef (O'Kiely and Moloney, 2002) and dairy (Leaver and Hill, 1995; Phipps et al., 1995) cattle. Furthermore, Phipps et al. (1995) reported similar increased feed intake characteristics with the replacement of grass silage with either maize or whole-crop cereal silages. In the current study the whole-crop wheat had lower digestibility characteristics relative to the grass silage. Using the equations of Steen et al. (1998) for beef cattle and Keady et al. (2004) for dairy cows, including whole-crop wheat as 0.40 in grass silage-based diets would be predicted to produce an increase of 0.36 and $0.30 \mathrm{~kg}$ DM per head per day or 0.05 and 0.03 respectively for forage only diets. The higher intake characteristics of whole-crop wheat silage relative to grass silage are not related to digestibility, as the whole-crop wheat silage in this study had lower digestibility characteristics. However, as with the maize silage, the intake characteristics are probably associated with DM and starch concentrations and fermentation characteristics.

Increasing concentrate supplementation resulted in a mean substitution of $0.53 \mathrm{~kg}$ silage DM per $\mathrm{kg}$ increase in concentrate DM intake which is similar to the range quoted by McNamee et al. (2001) for similar grass silages supplemented with similar levels of concentrate.
Steer performance

While whole-crop wheat silage inclusion increased liveweight gain, it had no beneficial effect on saleable product from finishing beef cattle, namely carcass weight. Similarly, previous studies have reported that the inclusion of wholecrop wheat silage in silage-based diets decreased carcass gain of beef cattle (O'Kiely and Moloney, 1999), had no effect on milk yield or composition of dairy cows (Leaver and Hill, 1995) or increased carcass gain of finishing beef cattle (O'Kiely and Moloney, 2002). More recently Keady (2005) concluded from a review of seven beef cattle and 20 dairy cow studies that whole-crop wheat silage inclusion in grass silage based diets did not improve either carcass gain of beef cattle or milk yield of lactating dairy cows.

The decrease in dressing proportion due to the inclusion of whole-crop wheat silage is probably associated with the increased intake of lower digestible forage. Previously Steen et al. (2002) reported that feeding medium feed value grass silage decreased dressing proportion relative to high feed value grass silage. Furthermore, O'Kiely and Moloney (1999) found that, relative to grass silage offered as the sole forage, whole-crop wheat silages ensiled at different DM concentrations and treated with different additives, decreased dressing proportion when offered as the sole forage to beef cattle. However, more recently it is noted that O'Kiely and Moloney (2002) observed no effect of the inclusion of whole-crop wheat on the dressing proportion of finishing beef cattle.

Previous authors have reported either decreased performance of beef cattle (O'Kiely and Moloney, 1995) or increased performance of beef (Browne et al., 1999) and dairy (Phipps et al., 2000; Keady et al., 2002b and 2003) cattle as a result of replacing a proportion of the forage component of grass silage-based diets with maize silage. More recently Keady (2005) concluded from a review of nine beef cattle and 34 dairy cow studies that including maize in grass silage based diets increased milk yield of lactating dairy cows by $1.4 \mathrm{~kg} /$ day and carcass gain of beef cattle by $0.11 \mathrm{~kg} / \mathrm{day}$ respectively. Unlike the effect of including whole-crop wheat silage, maize silage inclusion in the diet did not alter dressing proportion, similar to the results of McCabe et al. (1995) and O'Kiely and Moloney (2000). The absence of an effect to the inclusion of maize silage in grass silage-based diets on carcass conformation and fat classification and weights of internal fat depths, concurs with the findings of previous authors (McCabe et al., 1995).

Tenderness, colour and flavor are the major factors affecting meat quality (Devine and Chrystall, 1998). In the present study forage type did not alter fat and lean colour, or meat quality. O'Sullivan et al. (2002) concluded grass silage had higher vitamin $\mathrm{E}$ concentrations than maize silage and that beef from heifers offered grass silage-based diets had better overall quality in terms of colour, lipid oxidation, and vitamin $\mathrm{E}$ levels than beef from heifers offered forage-based diets where maize silage either partially or 
Silage type and performance and meat quality in beef cattle

totally replaced the grass silage. However, contrary to the present study, Hoving-Bolink et al. (1999) observed that totally replacing grass silage with maize silage in foragebased diets produced lighter and more tender beef. However, Hoving-Bolink et al. (1999) and Moloney et al. (1999) also observed that partial replacement of grass silage with maize silage did not alter meat colour or quality.

Increased marbling has been associated with improved meat eating quality (Jones et al., 1991; Wheeler et al., 1994). While in the present study partial replacement of grass silage with maize silage increased carcass gain, marbling fat or estimated carcass fat content were not altered, which may explain the absence of an effect on instrumental measures of meat quality. Marbling and intramuscular fat are generally related to juiciness assessed by sensory panels and may influence cooking loss. It should be noted that the average shear force value as measured by Warner Bratzler method indicated meat of acceptable tenderness based on the 100\% tenderness acceptability obtained for Warner Bratzler values of less than $3.0 \mathrm{~kg}$ by Miller et al. (2001). The low Warner Bratzler shear force values are probably due to the tenderstretch method used to hang the carcasses post slaughter which may have eliminated any treatment effects. Lively et al. (2005) observed differences in shear force between the Charolais and Holstein genotypes when the carcasses were suspended from the aitch bone but not when suspended from the achilles tendon. Although sarcomere length was statistically different due to level of concentrate feeding the difference in sarcomere length is small and of no practical significance. It should also be noted that while concentrate feed level increased lean colour, i.e. a more saturated colour, and tended to increase both marbling fat $(P=0.06)$ and estimated carcass fat $(P=0.09)$ concentrations, meat quality as determined by instrumental methods was unaltered. Postslaughter factors such as applied chilling rate, which interacts with fat cover and carcass size to give the resultant chilling rate within the muscle and the rate of $\mathrm{pH}$ fall, and the method of hanging all influence meat quality, particularly tenderness (Thompson, 2002). Where post-slaughter conditions are optimised, meat quality is more consistent.

Although the inclusion of maize and whole-crop wheat silages increased ME intake by 0.07 and 0.04 , carcass gains were altered by +0.17 and -0.04 ; respectively. The efficiency with which ME intake has been stored in the carcass has been calculated for the treatments and is presented in Table 7. Forage maize inclusion in the diet resulted in the lowest food conversion ratio ( $\mathrm{kg}$ DMI per $\mathrm{kg}$ carcass) and increased carcass gain per MJ ME intake, being higher than increasing concentrate feed level by $2 \mathrm{~kg}$ per head per day. For calculation of energy stored in the carcass, energy concentrations of 23.6 and $39.3 \mathrm{MJ} / \mathrm{kg}$ have been assumed for protein and lipid respectively. Protein and lipid concentrations of 220 and $46 \mathrm{~g} / \mathrm{kg}$ lean and 34 and $850 \mathrm{~g} / \mathrm{kg}$ for separable fat have been assumed, as these concentrations have been obtained for these tissues in previous studies (Steen and Robson, 1995). On this basis, the efficiency with which ME was stored in the
Table 7 Effects of silage type and concentrate feed level on estimated efficiency of gain

\begin{tabular}{|c|c|c|c|c|c|}
\hline & \multicolumn{3}{|c|}{ Silage } & \multicolumn{2}{|c|}{$\begin{array}{l}\text { Concentrate } \\
\text { (kg/day) }\end{array}$} \\
\hline & Grass & $\begin{array}{l}\text { Grass plus } \\
\text { maize }\end{array}$ & $\begin{array}{l}\text { Grass plus } \\
\text { whole crop }\end{array}$ & 3 & 5 \\
\hline $\begin{array}{l}\text { Food conversion ratio } \\
\text { (kg DMI/kg carcass) }\end{array}$ & 16.3 & 15.1 & 18.4 & 16.4 & 16.5 \\
\hline $\begin{array}{l}\text { Carcass gain } \\
\text { (g/MJ ME intake) }\end{array}$ & 4.94 & 5.42 & 4.59 & 5.05 & 4.96 \\
\hline Energy stored in carcass & & & & & \\
\hline (MJ/day) & 5.0 & 5.9 & 4.8 & 4.9 & 5.6 \\
\hline (KJ/MJ ME intake) & 47.9 & 53.1 & 44.5 & 48.2 & 49.2 \\
\hline
\end{tabular}

carcass (MJ/day) was 0.18 greater and 0.04 lower for diets containing maize and whole-crop wheat silages relative to grass silage-based diets. When efficiency of utilisation of ME is determined as energy stored in the carcass per MJ ME intake, maize silage inclusion in the diet increased efficiency of ME utilisation by 0.11 while whole-crop wheat decreased it by 0.07 . Meanwhile increasing concentrate feed level improved energy stored in the carcass per MJ ME intake by 0.02 . Data from this study illustrate that increased ME intake from the inclusion of forage maize silage in grass silage-based diets increased the efficiency of utilisation of ME relative to increasing concentrate feed level. Nitrogen is a primary environmental concern due to losses of ammonia to the atmosphere and nitrate contamination of the surface water and ground water (Tamminga, 1992). The increased $N$ retention by cattle offered the mixed forage diets, relative to grass silage only, is a desirable effect considering impending legislation limiting the quantity of organic-N loading per ha per year.

One of the potential benefits of including alternative forages in the diet would be to maintain animal performance at a lower concentrate feed level. Keady et al. (2002b and 2003) reported that with dairy cows, replacing 0.40 of the forage component of grass silage-based diets with maize silage resulted in concentrate sparing effects of up to 3.4 and $3.1 \mathrm{~kg}$ per cow per day. However, the potential concentrate sparing effect will depend on the feed value of the grass silage and alternative forage silage. In the present study using medium feed value grass silage, the concentrate sparing effect of maize and whole-crop wheat was greater than 2 and $0 \mathrm{~kg}$ per head per day respectively. Previously Keady et al. (2003) observed that for low, medium and high feed value grass silage-based diets, replacing 0.40 of the forage component with maize silage had concentrate sparing effects of $3.3,2.6$, and $2.5 \mathrm{~kg}$ per cow per day respectively.

It is concluded that replacing grass silage with maize silage increased carcass gain and weight of finishing beef cattle due to higher intakes and improved utilisation of metabolisable energy. While replacing grass silage with whole-crop wheat silage increased live-weight gain, the reduced dressing proportion resulted in no beneficial 
effect on carcass gain probably due to increased food intakes of lower digestible forage increasing gut fill.

\section{Acknowledgements}

Financial funding for this study, from the Department of Agriculture and Rural Development, is gratefully acknowledged. The authors wish to thank Mr K Mathers and the staff of the Beef Unit and Mr M Porter and the Laboratory staff for their assistance.

\section{References}

Agricultural Research Council 1965. Recommended procedures for use in the measurement of beef cattle carcasses. Agricultural Research Council, London. Bartholomew PW and Chestnutt DMB 1979. An assessment of the feasibility of forage maize production in Northern Ireland. Record of Agriculture Research, Department of Agriculture Northern Ireland 25, 17-23.

Browne EM, Bryant MJ and Beever DE 1999. Intake, growth rate and carcass quality of beef cattle fed maize silage harvested at three stages of maturity. Proceedings of the British Society of Animal Science, p. 83.

Cross HR, West RL and Dutson TR 1981. Comparison of methods for measuring sarcomere length in beef semitendinosus muscle. Meat Science 5, 261-266.

Cuthbertson A, Harrington G and Smith RJ 1972. Tissue separation: to assess beef and lamb variation. In Proceedings of British Society of Animal Production (ed. M Bichard), pp. 113-122.

Devine CE and Chrystall BB 1998. Meat science. Encyclopedia of food science and technology, second edition (ed. G Collins), Wiley Interscience, J. Wiley and Sons Inc, New York.

Easson DL 2000. The effects of plastic mulch on the growth and development of forage maize in Northern Ireland. The 73rd annual report. Agricultural Research Institute of Northern Ireland pp. 41-49. ARINI, Belfast.

Hameleers A 1998. The effects of the inclusion of maize silage, fermented whole crop wheat or urea-treated whole crop wheat in a diet based on a high-quality grass silage on the performance of dairy cows. Grass and Forage Science 53, 157-163.

Hoving-Bolink HA, Hanekamp WJA and Walstra P 1999. Effects of diet on carcass, meat and eating quality of once to bred Piemontese $\times$ Friesian heifers. Livestock Production Science 57, 267-272.

Jones SDM, Jeremiah LE, Tong AKW, Lutz S and Robertson WM 1991. The effect of marbling level, electrical stimulation, and post-mortem aging on the cooking and palatability properties of rib-eye steaks. Canadian Journal of Animal Science 71, 1037-1043.

Keady TWJ 2000. Beyond the science: what the farmer looks for in the production of silage. In Biotechnology in the feed industry. Proceedings of Alltech's 16th annual symposium (ed. TP Lyons and KA Jacques), pp. 439-452, Nottingham University Press, Nottingham.

Keady TWJ 2003. Maize silage in the diet of beef and dairy cattle - the influence of maturity at harvest and grass silage feed value, and feeding value relative to whole crop wheat. Agricultural Research Institute of Northern Ireland, 76th annual report pp. 43-54. ARINI, Belfast.

Keady TWJ 2005. Ensiled maize and whole crop wheat forages for beef and dairy cattle: effects on animal performance. In Silage production and utilization. Proceedings of the XIVth international silage conference (ed. RS Park and MD Stronge), pp. 65-82 Wageningen Academic Publishers, The Netherlands.

Keady TWJ and Kilpatrick DJ 2005. Prediction of carcass weight from live weight. Proceedings of the British Society of Animal Science, p. 179.

Keady TWJ, Kilpatrick CM, Cushnahan A and Murphy JA 2002a. The cost of producing and feeding forages. Proceedings of the XIllth international silage conference pp. 322-323. Auchincruive, Scotland.

Keady TWJ, Mayne CS and Kilpatrick DJ 2002b. The effect of maturity of maize silage at harvest on the performance of lactating dairy cows offered two contrasting grass silages. Proceedings of the British Society of Animal Science, p. 16.
Keady TWJ, Mayne CS and Kilpatrick DJ 2003. The effect of maturity of maize silage at harvest on the performance of lactating dairy cows offered three contrasting grass silages. Proceedings of the British Society of Animal Science, p. 126.

Keady TWJ, Mayne CS and Marsden M 1998. The effects of concentrate energy source on silage intake and animal performance with lactating dairy cows offered a range of grass silages. Animal Science 66, 21-33.

Keady TWJ, Mayne CS, Fitzpatrick DA and Marsden M 1999. The effects of energy source and level of digestible undegradable protein in concentrates on silage intake and performance of lactating dairy cows offered a range of grass silages. Animal Science 68, 763-777.

Keady TWJ, Mayne CS, Offer NW and Thomas C 2004. Prediction of voluntary intake. In Feed into milk - a new applied feeding system for dairy cows (ed. C Thomas), pp. 1-10. Nottingham University Press, Nottingham.

Keady TWJ, Steen RWJ, Kilpatrick DJ and Mayne CS 1994. Effects of inoculant treatment on silage fermentation, digestibility and intake by growing cattle. Grass and Forage Science 49, 284-294.

Kempster AJ, Cuthbertson A and Harrington G 1982. Carcase evaluation in livestock breeding, production and marketing. Granada Publishing, London.

Koolmees PA, Korteknie F and Smulders FJM 1986. Accuracy and utility of sarcomere length assessment by laser diffraction. Food Microstructure 5, 71-76.

Large EC 1954. Growth stages in cereals. Illustrations of the Feeke's scale. Plant Pathology 3, 128-129.

Leaver JD and Hill J 1995. The performance of dairy cows offered ensiled whole-crop wheat, urea-treated whole-crop wheat or sodium hydroxide-treated wheat grain and wheat straw in a mixture with grass silage. Animal Science 61, 481-490.

Lindsay JA and Davies HL 1981. Dietary N concentration in growing cattle: the effect on growth rate, feed utilization and body composition. Animal Production 32, 85-93.

Lively FO, Keady TWJ, Moss BW, Patterson DC and Kilpatrick DJ 2005. The effect of genotype, carcass weight and fat classification, and pelvic hanging technique on meat quality. Proceedings of the British Society of Animal Science, p. 59.

McAllister JSV 1961. Nitrogen top-dressing for maize. The 35th annual report of the Agricultural Research Institute of Northern Ireland, 1960-1961, pp. 36-37.

McCabe NH, O'Mara FP and Caffrey PJ 1995. Evaluation of maize silage in the diet of finishing steers. Proceedings of the British Society of Animal Science, p. 162.

McNamee BF, Kilpatrick DJ, Steen RWJ and Gordon FJ 2001. The prediction of grass silage intake by beef cattle receiving barley-based supplements. Livestock Production Science 68, 25-30.

Miller MF, Corr MA, Ramsey CB, Crockett KL and Hoover LC 2001. Consumer thresholds for establishing the value of beef tenderness. Journal of Animal Science 79, 3062-3068.

Moloney AP, Mooney MT, O'Kiely P and Troy DJ 1999. Fat colour and the quality of meat from beef cattle offered grass silage or maize silage-based diets. Proceedings of the XIII international silage conference, Sweden 309310.

O'Kiely P and Moloney AP 1995. Performance of beef cattle offered different ratios of grass and maize silage. Irish Journal of Agriculture and Food Research 34, 76.

O'Kiely P and Moloney AP 1999. Whole crop wheat silage for finishing beef heifers. Irish Journal of Agriculture and Food Research 38296.

O'Kiely P and Moloney AP 2000. Nutritive value of maize and grass silage for beef cattle when offered alone or in mixtures. Proceedings of the Agricultural Research Forum pp. 99-100.

O'Kiely P and Moloney AP 2002. Nutritive value of whole crop wheat and grass silage for beef cattle when offered alone or in mixtures. Proceedings of the Agricultural Research Forum, p. 42.

O'Sullivan A, O'Sullivan K, Galvin K, Moloney AP, Troy DJ and Kerry JP 2002. Grass silage versus maize silage effects on retail packaged beef quality. Journal of Animal Science 80, 1556-1563.

Phipps RH, Sutton JD and Jones BA 1995. Forage mixtures for dairy cows: the effect on dry matter intake and milk production of incorporating either fermented or urea treated whole-crop wheat, brewers grains, fodder beet or maize silage into diets based on grass silage. Animal Science 61, 491-496. 
Phipps RH, Sutton JD, Beever DE and Jones AK 2000. The effect of crop maturity on the nutritional value of maize silage for lactating dairy cattle. 3 . Food intake and milk production. Animal Science 71, 401-409.

Porter MG and Murray RS 2001. The volatility of components of grass silage on oven- drying and inter-relationships between dry matter content estimated by different analytical methods. Grass and Forage Science 56, 405-411.

Sinclair LA, Wilkinson RG and Ferguson DMR 2003. Effects of crop maturity and cutting height on the nutritive value of fermented whole crop wheat and milk production in dairy cows. Livestock Production Science 81, 257-269.

Steen RWJ 1984. A comparison of two-cut and three-cut systems of silage making for beef cattle using two cultivars of perennial ryegrass. Animal Production 38, 171-179.

Steen RWJ, Gordon FJ, Dawson LER, Park RS, Mayne CS, Agnew RE, Kilpatrick DJ and Porter MG 1998. Factors affecting the intake of grass silage by cattle and prediction of silage intake. Animal Science 66, 115-127.

Steen RWJ and Kilpatrick DJ 1995. Effects of plane of nutrition and slaughter weight on the carcass composition of serially slaughtered bulls, steers and heifers of three breed crosses. Livestock Production Science 43 , 205-213.

Steen RWJ and Kilpatrick DJ 2000. The effects of the ratio of grass silage to concentrates in the diet and restricted dry matter intake on the performance and carcass composition of beef cattle. Livestock Production Science 62, 181-192.

Steen RWJ, Kilpatrick DJ and Porter MG 2002. Effects of the proportions of high or medium digestibility grass silage and concentrates in the diet of beef cattle on liveweight gain, carcass composition and fatty acid composition of muscle. Grass and Forage Science 57, 279-291.

Steen RWJ and Robson AE 1995. Effects of forage to concentrate ratio in the diet and protein intake on the performance and carcass composition of beef heifers. Journal of Agricultural Science 125, 125-135.

Tamminga S 1992a. Nutrition management of dairy cows as a contribution to pollution control. Journal of Dairy Science 75, 345-357.

Thompson J 2002. Managing meat tenderness. Meat Science 62, 295-303.

Wheeler TL, Cunduff LV and Koch KM 1994. Effect of marbling degree on beef palatability in Bos taurus and Bos indicus cattle. Journal of Animal Science 72, 3145-3153. 